\title{
Sizing and Location Optimization of DSTATCOM in Radial Distribution System
}

\author{
T. Yuvaraj, P. Siva Teja, R. Hariharan, G. S. Mahesh
}

\begin{abstract}
A huge review on greatest allocation of Distribution Static Compensator (DSTATCOM) strategies in Radial Distribution system (RDS) device for compensation of reactive power $(Q)$, mitigation of electricity losses and enhancement in voltage profile is presented. DSTATCOM compensates bus voltage to restriction the strength factor, in addition with energetic and additionally reactive power flows in the RDS. It can additionally provide immediate and non-stop capacitive $(C)$ and inductive $(L)$ mode compensation. This system also injects quantity of lead or lagging compensating current, when it is connected with a same load or varying load. Various IEEE buses are used for checking the achievability of the optimization methods in distribution system. In few papers the presented approach is evaluated through evaluating it with previous techniques and benefits are shown by means of simulation results.
\end{abstract}

Keywords : DSTATCOM (Distributed Static Compensator), Radial Distribution System (RDS), Optimization Techniques.

\section{INTRODUCTION}

$\mathrm{T}$ he modern-day society is such a lot structured ahead the utilization of electrical energy that it raised to develop into part of our living. Generation, transmission as properly as distribution are fundamental for electric powered strength system. It is regulated either by using range of entities or via single entity. For the gain of society, construction, layout, protection of varies electric powered provide schemes with technology and clinical records. To supply superb electricity to the purchasers from transmission is the precept cause of the distribution device. Though, a major part of the electric strength that a benefit makes is lost within the DS [1]. With the help of trendy research, it is confirmed that at the distribution degree the energy that is generated is wasted as I2R losses. Majority of masses in circulation networks are inductive.

Because of this the community power trouble is lagging in countryside. Because of this, there can be poor voltage profile, boom in electrical energy losses and increased troubles would possibly be created inner the distribution

Revised Manuscript Received on December 11, 2019

* Correspondence Author

T. Yuvaraj, Assistant professor, Department of EEE, Saveetha School of India. Email: yuvaraj4252@gmail.com

P. Siva Teja, Department of EEE, Saveetha School of Engineering, Saveetha Institute of Medical and Technical Sciences, Chennai, India. Email: sivasanju8397@gmail.com

R.Hariharan, Department of EEE, Saveetha School of Engineering, Saveetha Institute of Medical and Technical Sciences, Chennai, India. Email: harinov22@gmail.com

G.S. Mahesh, Department of EEE, Sree Vidyanikethan Engineering College, A.Rangempet, Tirupati, India. Email: gs.mahesh01@gmail.com Engineering, Saveetha Institute of Medical and Technical Sciences, Chennai,

networks.

In India, common overall performance and economic issues of distribution machine can have direct impact of device losses. Due to this the energetic power losses share will be round $10-13 \%$. It is a very vital component to consider. Reduction in strength loss is measured as most essential issue, from consumer's side. In electrical energy grid, to keep a regular and secure operation voltages profile enhancement is essential. In DS, energy losses are divided into $\mathrm{P}$ and $\mathrm{Q}$ power losses.

Power exceptional enchantment electricity issue improvement, voltage profile enhancement and cut price of electricity losses are achieved with the aid of the usage of compensating devices. For this enormously superior system's like shunt reactors and series reactors, capacitor banks, Automatic Voltage Regulator and Distribution Network Flexible AC Transmission devices are Unified Power Flow Conditioner, Distribution Static Compensator (DSTATCOM) and Static Synchronous Series Compensator are used. [3, 5, 7, 18, 24]

Traditionally, within the distribution networks, shunt capacitors are used in dealing the reactive power compensation. But the drawbacks with shunt capacitor are

- Failures to produce continuous variable reactive power due to the failure of reactive power generation it expend additional value for installation of capacitors.

- It has few operational troubles corresponding resonance.

- Along with this, load balancing is now not possible

To get to the bottom of above-referred to drawbacks and to compensate the reactive electrical energy necessities DSTATCOM (DFACTS) is used in distribution organizations. Recently to beautify the electricity gorgeous the financial manner and nice manner is the use of power electronics specially based Distribution bendy AC transmission computer era [14]. To boost the system typical performance at strategic places of the sharing buildings D-FACTS devices are introduced. An efficient speedy and dependable manipulate is furnished by means of the DFACT units over distribution parameters [7].

The basic structure and principle of DSTATCOM is same as principle of DFACTS. The three major additives of DSTATCOM are (i) voltage provide converter linked as shunt, (ii) capacitor link and (iii) coupling transformer. An inverter with STATCOM device, energy storage device and a coupling transformer and is referred to as DSTATCOM and it has same configuration of STATCOM. 


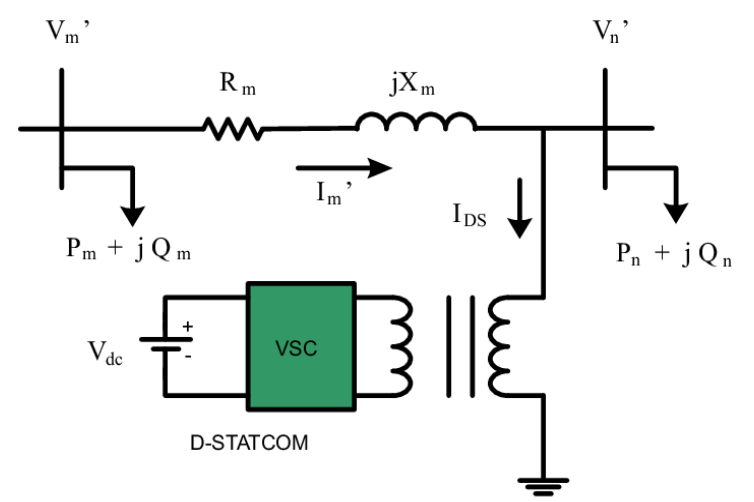

Fig. 1. Block Diagram of DSTATCOM

The bus voltage is compensated by means of means of DSTATCOM for controlling the power component, reactive and energetic power flows interior the RDS. DSTATCOM affords rapid and continuous capacitive and inductive mode reimbursement. This machine coupled with a particular load, it will inject sample quantity of lagging or main compensating modern. Hence, for the utility connection, the device desires to be met with the full demand [15]. Another area of expertise of this device is capable to minimize the effectiveness of voltage from any unbalance and harmonic distortion. Due to its boom in the strength gadget load, DSTATCOM is expected to rise out a foremost role in the RDS. Optimum allocation of DSTATCOM maximizes the subsequent constraints including, strength loss minimization, annual charge saving, load ability, balance enhancement, reactive electricity compensation and electricity excellent enchantment [17].

Proper arrangement of DSTATCOM is crucial to maximizing its benefits. Optimum region of this machine will increase the load ability, compensates reactive energy, enhances stability, and reduces electricity loss as nicely as improves the electricity quality. When the gadget is improperly positioned, it affects the system and moreover endanger the complete device manipulate and operation. Hence it's miles vital for primary sizing and location of the tool. The primary methods used for siting and sizing of DSTATCOM are labelled as follows:

(1) Modal analysis

(2) Analytical Techniques

(3) Optimization Techniques

\section{A. Modal Analysis}

The authors in [22] have implemented time-domain simulation and modal contrast for identifying the extremely good neighbourhood of DSTATCOM for energy satisfactory improvement inner the distribution network.

\section{B. Analytical Techniques}

The analytical strategies produce an algebraic expression and it could be examined for robustification and optimization. In these techniques the desktop is represented with the resource of a mathematical mannequin and computes numerical reply barring delay. Outcome of this strategy is accurate and required less computation time. It is simplistic and small device, in which the extent of state variables involved are less in range. Index approaches,
Sensitivity Based Method Point Estimation Method are the analytical techniques that are applied in 5, 6, 9 and 15. However, analytical techniques aren't splendid for massive and complicated systems, as it performs adversely with recognize to computational efficiency.

\section{Optimization Techniques}

From the available set of picks finding out the fantastic answer is the device of optimization. In famous as the dispersal systems have several nodes it is miles challenging to find out the most fantastic size and vicinity of the compensating devices manually. Numerous optimization strategies are used in the literature. A variety of of the strategies are acknowledged as classical optimization strategies. Intelligent strategies are the strategies which would possibly be successful in getting accurate, efficient perfect options in sensible way. Certain of the opposite strategies are meta-heuristic are looking for techniques.

However, in latest studies most of the researchers have used meta-heuristic algorithms. Meta- heuristic algorithms offer worldwide and present day nice reply in is looking for area. The few special techniques are miscellaneous techniques and future smart strategies. In a number of regions, for solving issues these strategies are most auspicious. Following are the various optimization methods such as Particle Swarm Optimization (PSO), Genetic Algorithm (GA), Bat Algorithm(BA), Fuzzy Common Sense (FCS), Differential Evolution Algorithm (DEA), Effective biologically stimulated Immune Algorithm (IA), Cuckoo Search Algorithm(CSA), Instantaneous energetic and reactive cutting-edge trouble thought (IARCC), Single section $\mathrm{p}-\mathrm{q}$ concept primarily based manage algorithm, Firefly Algorithm, Instantaneous Reactive Power Theory (IRPT) manipulate set of rules, Bacterial Foraging Optimization Algorithm (BFOA) and many others. Applied and cautioned by 1-5, 7, 8, and 10, 11-14 and 16-22.

The authors have proposed more than a few methods for top-rated sizing of DSTATCOM are tabulated under. Computational time is more in the proposed techniques. In spite of this, the authors were given fantastic consequences for the finest sizing and arrangement of DSTATCOM for reduction of power quality issues and voltage gain improvement in RDS. The proposed strategies by using capacity of the authors are examined on significant IEEE buses and efficaciously carried out. 
Table- I: Optimization Techniques, Test systems and advantages

\begin{tabular}{|c|c|c|c|c|}
\hline S.no & Authors and Year & Techniques & Test Systems & Advantages \\
\hline 1 & Jazebi,S., et.al, (2011) & DEA & $\begin{array}{l}\text { IEEE } 69 \text { and } 83 \\
\text { busses }\end{array}$ & $\begin{array}{l}\text { By its high computational search performance and correct } \\
\text { convergence homes, differential evolution set of rules in } \\
\text { distribution networks has tested its special abilities. }\end{array}$ \\
\hline 2 & $\begin{array}{l}\text { Zaveri, T., et.al. } \\
\qquad(2011)\end{array}$ & IRACC Theory & IEEE-519 bus & $\begin{array}{l}\text { Large variation in load and supply situations the strategies is } \\
\text { accurate and is powerful. It is also successful in lessening the } \\
\text { supply VA score balancing of supply currents and to attain power } \\
\text { issue correction in comparison to uncompensated case, beneath } \\
\text { various load conditions. }\end{array}$ \\
\hline 3 & $\begin{array}{l}\text { Zaveri, T., et.al. } \\
\qquad(2012)\end{array}$ & IARCC & IEEE-519 bus & $\begin{array}{l}\text { In linear load, power element correction is carried out. It low cost } \\
\text { in reactive power provided. For non-linear load, solidarity source } \\
\text { electricity element is attained. }\end{array}$ \\
\hline 4 & $\begin{array}{l}\text { Arya, S. R., et.al, } \\
\qquad(2012)\end{array}$ & $\begin{array}{l}\text { p-q theory based control } \\
\text { algorithm }\end{array}$ & $\begin{array}{l}\text { TMS320F240DSP } \\
\text { processor(dS } \\
\text { PACE1 } 104\end{array}$ & $\begin{array}{l}\text { Suitable in time varying loads for ZVR and PFC modes of } \\
\text { operation. }\end{array}$ \\
\hline 5 & $\begin{array}{l}\text { Khorram-Nia, R.,et.al, } \\
\text { (2013) }\end{array}$ & $\begin{array}{l}\text { Modified Bat Algorithm, } \\
\text { point estimate method } \\
\text { (PEM) }\end{array}$ & IEEE 69-bus & Effective \\
\hline 6 & $\begin{array}{l}\text { Hussain, S. S., \& } \\
\text { Subbaramiah, M. } \\
\text { (2013) }\end{array}$ & $\begin{array}{l}\text { Methodology considering } \\
\text { operational electrical } \\
\text { constraints }\end{array}$ & IEEE 33- bus & $\begin{array}{l}\text { For calculation of losses and strength waft it utilizes a simple load } \\
\text { waft inside the machine. }\end{array}$ \\
\hline 7 & $\begin{array}{l}\text { Farhoodnea, M., et.al, } \\
\text { (2013) }\end{array}$ & $\begin{array}{l}\text { Firefly algorithm(heuristic } \\
\text { optimization technique) }\end{array}$ & IEEE 16bus & The firefly algorithm is effective compared to PSO and GA. \\
\hline 8 & $\begin{array}{l}\text { Taher, S. A., \& Afsari, } \\
\text { S. A. (2014) }\end{array}$ & Immune Algorithm & $\begin{array}{l}\text { IEEE 33-and } \\
\text { 69-buses }\end{array}$ & $\begin{array}{l}\text { Convergence time of IA is faster than GA and surest solution } \\
\text { found by the IA is better than the GA technique. }\end{array}$ \\
\hline 9 & Jain,A., et.al, (2014) & Stability Index & IEEE 33-bus & Active power losses reduction and voltage profile improvement. \\
\hline 10 & $\begin{array}{l}\text { Mahendra Repalle, B., } \\
\text { et.al, (2014) }\end{array}$ & Fuzzy Inference System & IEEE 33-bus & $\begin{array}{l}\text { Implementation of the approach is observed to be quicker effective } \\
\& \text { clean. }\end{array}$ \\
\hline 11 & $\begin{array}{l}\text { Singh, B., et.al, } \\
(2015)\end{array}$ & $\begin{array}{l}\text { Self Tuning Filter based } \\
\text { Instantaneous Reactive } \\
\text { Power Theory Control } \\
\text { Algorithm }\end{array}$ & $\begin{array}{l}\text { DSP (Digital Signal } \\
\text { Processor dSPACE } \\
\text { 1104). }\end{array}$ & Effective way for power quality complications. \\
\hline 12 & $\begin{array}{c}\text { Devi, S., \& } \\
\text { Geethanjali, M. } \\
(2014)\end{array}$ & $\begin{array}{c}\text { Particle Swarm } \\
\text { Optimization Algorithm }\end{array}$ & $\begin{array}{l}\text { IEEE } 12,34 \text { and } 69 \\
\text { buses }\end{array}$ & $\begin{array}{l}\text { Total loss discount because of the placement of individual DG and } \\
\text { DSTATCOM at extraordinary places or on the equal bus. }\end{array}$ \\
\hline 13 & $\begin{array}{l}\text { Yuvaraj, T., et.al, } \\
\quad(2015\end{array}$ & Harmony Search Algorithm & IEEE 33-bus & $\begin{array}{l}\text { For n number of buses it may be applied. For finding most efficient } \\
\text { answers it is very accurate Better than the present Immune } \\
\text { algorithm. }\end{array}$ \\
\hline 14 & $\begin{array}{l}\text { Tolabi, H. B., et.al, } \\
\qquad(2015)\end{array}$ & Fuzzy-ACO Approach & IEEE 33-bus & $\begin{array}{l}\text { Simultaneous allocation and multi goal reconfiguration of } \\
\text { DSTATCOM and PV with fuzzy ACO approach is observed to be } \\
\text { better in comparison to ACO, fuzzy GA and Fuzzy-PSO }\end{array}$ \\
\hline 15 & $\begin{array}{l}\text { Gupta, A. R., et.al, } \\
\text { (2016) }\end{array}$ & Variational technique & IEEE 33-bus & $\begin{array}{l}\text { The loss reduction of PLI and VSI is higher in comparison with } \\
\text { other present strategies. }\end{array}$ \\
\hline 16 & $\begin{array}{l}\text { Devabalaji, K. R., \& } \\
\text { Ravi, K. (2016 }\end{array}$ & $\begin{array}{l}\text { Bacterial Foraging } \\
\text { Optimization Algorithm }\end{array}$ & $\begin{array}{l}\text { IEEE } 33 \text { and } \\
119 \text { buses }\end{array}$ & $\begin{array}{l}\text { Voltage profile improvement, reduction in loss, enhancement of } \\
\text { VSI and increase inside the gadget security degree is viable with } \\
\text { synchronized employment of DSTATCOM and DG. Less } \\
\text { computational time and worldwide convergence. }\end{array}$ \\
\hline 17 & $\begin{array}{c}\text { Gupta, A. R., \& } \\
\text { Kumar, A. (2015) }\end{array}$ & $\begin{array}{l}\text { Monte Carlo Simulation } \\
\text { (MCS) method }\end{array}$ & $\begin{array}{l}\text { IEEE } 85 \text { and } 54 \\
\text { buses }\end{array}$ & $\begin{array}{l}\text { Due to the position of DSTATCOM there may be voltage profile } \\
\text { development and electricity losses discount }\end{array}$ \\
\hline 18 & $\begin{array}{l}\text { Yuvaraj, T., et.al, } \\
(2015)\end{array}$ & Bat algorithm & $\begin{array}{l}\text { IEEE } 33 \text { and } 69 \\
\text { buses }\end{array}$ & Decreases the total power loss. \\
\hline 19 & $\begin{array}{l}\text { G.Gowtham, } \\
\text { A.Lakshmi Devi } \\
(2015)\end{array}$ & $\begin{array}{l}\text { Particle Swarm } \\
\text { Optimization }\end{array}$ & $\begin{array}{l}\text { IEEE } 33 \text { and } 69 \\
\text { buses }\end{array}$ & $\begin{array}{l}\text { Voltage profile is maintained within limits and reduction in } \\
\text { normal loading }\end{array}$ \\
\hline 20 & $\begin{array}{l}\text { Mahela, O. P., \& } \\
\text { Shaik, A. G. (2016) }\end{array}$ & IEEE 33 and 69 buses & IEEE 13 Bus & $\begin{array}{l}\text { Improvement in electricity high-quality events that are related to } \\
\text { wind operations which include grid synchronization of wind } \\
\text { generator and its output and variation of wind speed. }\end{array}$ \\
\hline 21 & $\begin{array}{l}\text { Yuvaraj, T., et.al, } \\
\quad(2017)\end{array}$ & $\begin{array}{l}\text { Cuckoo Search } \\
\text { Optimization Algorithm }\end{array}$ & $\begin{array}{c}\text { IEEE } 12,34 \text { and } \\
69 \text {-bus }\end{array}$ & $\begin{array}{l}\text { In tuning the manage parameters, in comparison to other } \\
\text { algorithms, it does no longer need to spend greater attempt. For } \\
\text { any big scale and real time distribution system, it can be without } \\
\text { problems applied. }\end{array}$ \\
\hline 22 & $\begin{array}{l}\text { Thangaraj,Y., \& } \\
\text { Kuppan, R. (2017) }\end{array}$ & $\begin{array}{l}\text { Novel Lightning Search } \\
\text { Algorithm }\end{array}$ & IEEE 33 and 69- bus & Higher voltage profile improvement. \\
\hline 23 & $\begin{array}{l}\text { Adel ali abou } \\
\text { EL-Ela., et.al, }\end{array}$ & Java algorithm & IEEE 69-bus & $\begin{array}{l}\text { Increase voltage gain, reducing the power losses in DS line and } \\
\text { efficiency of the DS due to R/X ratio. For that reason, maximum } \\
\text { number of devices utilized in DS and that maintain the voltage } \\
\text { amplitude at satisfactory range. }\end{array}$ \\
\hline 24 & Balamuruga,P., et.al, & $\begin{array}{l}\text { Whale Optimization } \\
\text { Algorithm }\end{array}$ & IEEE 69-bus & $\begin{array}{l}\text { High R/X ratio in DS causes poor power quality in a distribution } \\
\text { system. Its major drawbacks are voltage drop, lagging power } \\
\text { factor and instability and it produce large power losses, less } \\
\text { voltage profile and create network security problems in RDS. }\end{array}$ \\
\hline
\end{tabular}




\section{CONCLUSION}

This study is particularly centered on most environments friendly allocation of DSTATCOMs in distribution networks the use of more than a few techniques. In addition, it additionally furnished the distribution computer operation, voltage profile, system losses, performance, balance, reliability, load ability and power excellent and many others, via insertion of DSTATCOM. It moreover supplied the advantages and negative aspects by using the setup of DSTATCOM. Many researchers achieved and applied a range of techniques for superior sizing and web site of DSTATCOM. This have a look at additionally reveals that the researches carried their works with the resource of questioning about unmarried aim or multi-goal problem for discovering international most effective, by and large the ones having various neighbourhood optima. By the usage of newly brought techniques the unconstraint are successfully dealt with. The strategies are examined on several IEEE take a look at buses.

\section{FUTURE SCOPE}

In the furnish community via using the mixture or extra strategies or hybrid strategies for set up of DSTATCOM, better effects may additionally be received. For protection and growth of present day distribution systems, the installation of DSTATCOM's utility may additionally be prolonged. It is feasible to analyze mesh distribution system. It is feasible to perform dynamic analysis with DSTATCOM in distribution network to analyze the effectiveness of the machine..

\section{REFERENCES}

1. Adegboyega Gabriel, A., and Franklin ,o.“ Determination of Electric Power Losses in Distribution Systems " , Latin America: IEEE/PES Transmission \& Distribution Conference and Exposition, 2006, (pp. 1-5).

2. Arya, S. R., Singh, B., Chandra, A., and Al-Haddad, K, Power factor correction and zero voltage regulation in distribution system using DSTATCOM. Electronics, Drives and Energy Systems (PEDES), 2012 IEEE International Conference, pp. 1-6, 2012

3. 3.Balamurugan, P., Yuvaraj, T., and Muthukannan, P. Optimal Allocation of DSTATCOM in Distribution Network Using Whale Optimization Algorithm. Engineering. Technology \& Applied Science Research, vol. 8, no.5, pp.3445-3449, 2018.

4. Devi, S., and Geethanjali, M. "Optimal location and sizing determination of Distributed Generation and DSTATCOM using Particle Swarm Optimization algorithm". International Journal of Electrical Power \& Energy Systems, vol. 62, pp. 562-570, 2014.

5. EI-Ela, A. A. A., Mouwafi, M. T., Shammah, A. E. S., and Abdel-Ghany, D. Y. "Optimal Placement of D-STATCOM in Distribution Systems Using JAYA Algorithm". In 2018 Twentieth International Middle East Power Systems Conference, pp. 834-838, 2018.

6. Farhoodnea, M., Mohamed, A., Shareef, H., and Zayandehroodi, H. "Optimum D- STATCOM placement using firefly algorithm for power quality enhancement". In Power Engineering and Optimization Conference (PEOCO), 7th International, pp. 98-102, 2013.

7. G. Gowtham, and Prof. A. Lakshmi Devi "Power Loss Reduction and Voltage Profile Improvement by DSTATCOM using PSO” International Journal of Engineering Research \& Technology (IJERT) ISSN: 2278-0181 IJERTV4IS020483 www.ijert.org Vol. 4 no. 02, 2015.

8. Gupta, A. R., and Kumar, A. "Energy savings using D-STATCOM placement in radial distribution system". Procedia Computer Science, vol. 70, pp. 558-564, 2015.

9. Gupta, A. R., and Kumar, A. "Optimal placement of D-STATCOM in distribution network using new sensitivity index with probabilistic load models". In Recent Advances in Engineering \& Computational Sciences (RAECS), 2015 2nd International Conference on pp. 1- 6, 2015.
10. Shalini, P., and Keerthivasan, M. "Voltage Sag Compensation Using Distribution Static Compensator (DSTATCOM)", International Journal of Advances in Signal and Image Sciences, vol. 1, no. 1, pp. 19-28, 2015.

11. Jain, A., Gupta, A. R., and Kumar, A. "An efficient method for D-STATCOM placement in radial distribution system". In Power Electronics (IICPE), 2014 IEEE 6th India International Conference, pp. $1-6,2014$.

12. Khorram-Nia, R., Baziar, A., and Kavousi-Fard, A. "A novel stochastic framework for the optimal placement and sizing of distribution static compensator". Journal of Intelligent Learning Systems and Applications, vol. 5, no. 02, pp.90, 2013.

13. Mahendra Repalle, B., Mercy Rosalina, K., and Prema Kumar, N. "Fuzzy logic based optimal location and sizing of DSTATCOM in radial distribution systems". Int J Adv Technol Eng Sci, vol. 2, pp.122-129, 2014.

14. Mahela, O. P., and Shaik, A. G. "Power quality improvement in distribution network using DSTATCOM with battery energy storage system". International Journal of Electrical Power \& Energy Systems, vol. 83, pp. 229-240, 2016.

15. Rogers, K. M., and Overbye, T. J. "Some applications of Distributed Flexible AC Transmission System (D-FACTS) devices in power systems". In Power Symposium, NAPS'08. 40th North American, pp. 1-8, 2008.

16. Sensarma, P. S., Padiyar, K. R., and Ramanarayanan, V. "Analysis and performance evaluation of a distribution STATCOM for compensating voltage fluctuations". IEEE Transactions on Power Delivery, vol. 16, no. 2, pp. 259-264, 2001.

17. Singh, B., Dube, S. K., and Arya, S. R. (2015). “An improved control algorithm of DSTATCOM for power quality improvement”. International Journal of Electrical Power \& Energy Systems, vol. 64, pp. 493-504, 2015 .

18. Shalini, Priyanga, and M. Keerthivasan. Voltage Sag Compensation Using Distribution Static Compensator (Dstatcom), “International Journal Of Advances In Signal And Image Sciences, vol. 1, no. 1 2015, pp. 19-28.

19. Taher, S. A., and Afsari, S. A. (2014). "Optimal location and sizing of DSTATCOM in distribution systems by immune algorithm". International Journal of Electrical Power \& Energy Systems, vol. 60, pp.34-44, 2014.

20. Tolabi, H. B., Ali, M. H., and Rizwan, M. "Simultaneous reconfiguration, optimal placement of DSTATCOM, and photovoltaic array in a distribution system based on fuzzy-ACO approach" IEEE Transactions on sustainable Energy, vol. 6, no. 1, pp. 210-218, 2015.

21. Wasiak, I., Mienski, R., Pawelek, R., and Gburczyk, P. “Application of DSTATCOM compensators for mitigation of power quality disturbances in low voltage grid with distributed generation" In Electrical Power Quality and Utilizations, pp. 1-6, 2007.

22. Zaveri, T., Bhalja, B. R., and Zaveri, N. "A novel approach of reference current generation for power quality improvement in three-phase, three-wire distribution system using DSTATCOM". International Journal of Electrical Power \& Energy Systems, vol. 33, no. 10, pp. 1702-1710, 2011.

23. Zaveri, T., Bhalja, B. R., and Zaveri, N. "Load compensation using DSTATCOM in three-phase, three-wire distribution system under various source voltage and delta connected load conditions". International Journal of Electrical Power \& Energy Systems, vol. 41, no.1, pp. 34-43, 2012.

24. Zulkifli, S. A., Ahmad, M. Z., Hamdan, R., and Bujal, N. R. (2009). "Determination of location and number of D-STATCOM at the distribution network". Compilation of Papers 2009-vol. 2, 2009.

25. Devabalaji, K. R., Yuvaraj, T., and Ravi, K. "An efficient method for solving the optimal sitting and sizing problem of capacitor banks based on cuckoo search algorithm". Ain Shams Engineering Journal, 2016.

\section{AUTHORS PROFILE}

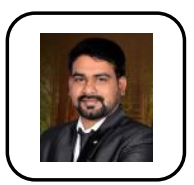

Dr.T.Yuvaraj is currently working as an Assistant professor of Department of EEE in Saveetha School of Engineering, Chennai, India. He has completed his Ph.D degree from VIT University, Vellore in 2017. He received his B.E degree in electrical and electronics engineering in 2011 and his M.E degree in power electronics in 2013 both from Anna University, Chennai, India.His research interests are optimal allocation of compensating devices in the distribution networks using optimization algorithms. He has published more than 28 Scopus indexed journals and has also served as reviewer to some reputed journals. He is the Member of IET and IAENG 
P.SivaTeja, is the student of departmentof Electrical and Electronics engineering, SaveethaSchool of Engineering, SIMTS, Chennai

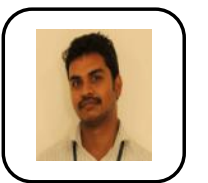

Dr.R.Hariharanis currently working as an AssociateProfessor of Department of EEE in Saveetha School of Engineering, Chennai, India. He has completed his Ph.D degree from Saveetha University, Chennai in 2018. He received his B.E degree in electrical and electronics engineering in 2009 and his M.E degree in Embedded System in 2012. His research interests are Blackout restoration and artificial intelligence. He has published more than 34 Scopus indexed journals and he is the Member of IET and IAENG

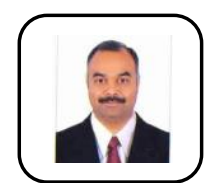

G Sreeramulu Mahesh received the B.E. degreefrom MSRIT, Bangalore, India, in 1997, the M.E. degreefrom Hindusthan College of Engineering, Chennai, India,in 2001, and the Ph.D. degree from the VisvesvarayaTechnological University, Belgaum, India, in 2018. Atpresent, working as Associate ProfessorinSreeVidyanikethan College of Engineering, Tirupati. Power Quality, Micro gridsand Smart Grids are the research areas. 